IRA-International Journal of Management \& Social Sciences

ISSN 2455-2267; Vol.05, Issue 02 (2016)

Pg. no. 367-384

Institute of Research Advances

http://research-advances.org/index.php/RAJMSS

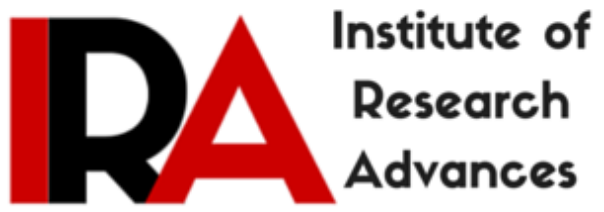

\title{
The Portuguese Settlement on the Coromandel Coast, a Case Study of San Thome and Nagapattinam in the Seventeenth Century
}

\author{
A S Shngreiyo \\ Centre for Historical Studies, \\ Jawaharlal Nehru University, New Delhi, India.
}

Type of Review: Peer Reviewed.

DOI: http://dx.doi.org/10.21013/jmss.v5.n2.p14

\section{How to cite this paper:}

Shngreiyo, A. (2016). The Portuguese Settlement on the Coromandel Coast, a Case Study of San Thome and Nagapattinam in the Seventeenth Century. IRA-International Journal of Management \& Social Sciences (ISSN 2455-2267), 5(2), 367-384. doi:http://dx.doi.org/10.21013/jmss.v5.n2.p14

(C) Institute of Research Advances

\section{(cc) BY-NC}

This work is licensed under a Creative Commons Attribution-Non Commercial 4.0 International License subject to proper citation to the publication source of the work.

Disclaimer: The scholarly papers as reviewed and published by the Institute of Research Advances (IRA) are the views and opinions of their respective authors and are not the views or opinions of the IRA. The IRA disclaims of any harm or loss caused due to the published content to any party. 


\begin{abstract}
The origin of the Saint Thomas, who is believed to be buried at Mylapur gradually led to the emergence of San Thome as an important trading post for the Portuguese in the Coromandel Coast. The Portuguese discovered the remnants of the Saint when they excavated the place and it become a major influence in their settlement of the town called San Thome. San Thome slowly developed as an urban center in the sixteenth century. The chapter also attempts to show the crucial role that the Portuguese played in the process of urbanization and in the social and political spheres as well. Down the coast lies another Portuguese port called Nagapattinam probable it was the first Portuguese to settle at Coromandel Coast in the 1520s. The first Portuguese settlers were mostly private traders interested in the rice trade to Sri Lanka. Later it become one of the flourishing ports as many individual Portuguese settle down and do commerce. It is said that more than seven hundred sailing vessels were frequently docked at the same time on the river. Every year these vessels carried more than twenty thousand measures of rice from here to the western Coast of India. The trade here attracted merchants from all parts of India as well as from Pegu, Malacca and Sumatra. However, both the port did not enjoy for long as it sweep away by the coming of other European countries in the following centuries.
\end{abstract}

Keywords: Growth of Portuguese Settlement on the Coromandel Coast, A Case Study of San Thome and Nagapattinam in the Seventeenth Century

In the beginning, probably the most attractive single thing for the Portuguese about the region on the other east side of the Cape of Comorin was the Legend of Saint Thomas the Apostle. The quest for Eastern Christians was at least as great as a magnet as was trade for wide-ranging Portuguese during the discovery era. As early as 1501, Pedro Alvares Cabral wrote to the king Dom Manuel I that, "St. Thomas was found on the sea coast, in a city which is called Maliapor, of a small population." further contact appears to have been made until 1517 when Portuguese merchants Diogo Ferandez and Bastiao Fernandez, while returning from a journey to Malacca, landed at Pulicat and stayed there with fellow Armeian Christians. These Christians invited them to join on a pilgrimage to a house five leagues from there, which was built by a holy man called St. Thomas.

Accordingly, the above-mentioned Portuguese merchants in the company of the Armenian Christians set out on the pilgrimage and arrived in Mylapur in March $1517 .^{2}$ It happened to be the first time for any Portuguese to visit Mylapur, as mentioned by H.D Love and A.M Mundadan. But Sanjay Subramanyam pointed out that one of the earliest recorded European visitors was Florritine Piero Stronzzi, who participated in the Portuguese attack on Goa in the late 1510, and is known to have been in Mylapur in 1515. Then again in 1516 accompanied by another Lorentine, Andrea Corsali, Florritine Piero Stronzzi returned together to visit Mylapur, using the land route from Pulicat. One of the enigmas of this period is the foundation stone of the church of Nossa Senhora Luz in Mylapur. According to some sources, the oldest European inscriptions in India, which stated Friar Pedro de Atougia, of the Franciscan order, built this church of Our Lady of Light in $1516 .^{3}$

The genesis of the tomb of St. Thomas in Mylapur began when Pedro Alvarez Cabral was approached by two native Christians, namely Joseph and Mathias, expressing their desire to go to Portugal and then finally visit Jerusalem. Though Mathias died after reaching Portugal, Joseph continued his journey to realize his dream. ${ }^{4}$ It was king Dom Manual I who encountered with Joseph

\footnotetext{
${ }^{1}$ Greenlee ,William. B, (ed.), (1938). The Voyage of Pedro Alvares Cabral to Brasil and India, p. 49.

2 Love, H. D, (1996). Vestiges of Old Madras, p. 287. See also A.M. Mundadan, "The Portuguese Settlement in Mylapore," Indian Church History Review, Vol. III, N0 I. June 1969. p.105. and his book. History of Christianity in India, (Bangalore, 1989), Vol. I, p.407.

${ }^{3}$ Subramanyam, Sanjay, (1990), Improvising Empire, pp. 48-89.

${ }^{4}$ Mundadan, A. M, (1984), History of Christianity in India, vol. 1, p. 403.
} 
in 1501 that gave definite information about the tomb of St. Thomas in Mylapur that play a major role for the Portuguese settlement in San Thome. Very soon, Don Manual I, the King of Portugal, sent official missions to Mylapur. The Governor, Durate de Meneses (1522-24), also sent commissions under Manual Frias as factor and captain of the Manaar and Coromandel Coast to inquire in the affairs of the tomb. Later a priest under Alvaro Penteado proceeds to inquire in detail about the affairs of the tomb. He made an elaborate plan for the repair, which did not please the Portuguese officials, as they were reluctant to involve themselves in a big financial commitment and were afraid that such an understanding would create suspicion in the minds of the rulers of the place. Penteado then left for Portugal in order to give in person an account to the king of Portugal, leaving behind in Mylapur a chaplain, an old priest Pero Fernandez and another Portuguese Diogo Lourence. Father Alvaro Penteado who had gone to Portugal came back with new commission directly from the king and arrived at Mylapur in 1525 as its vicar. Pretending that the relics, which are excavate when he was away in June 1523, were not safe in the place where they kept at that time in a wooden box buried them in a place unknown to all except one Rodrigo Alveres. Father Penteado soon came into conflict with the local Portuguese officials for various reasons. He was also attack by Muslims merchant and was seriously wounded. All these forced him to retire from Mylapur in 1530 after that a new vicar one Fr. Ugo Nicolo, was appointed. The new vicar at the request of the Portuguese citizens of Mylapur unearthed the relics and displayed them in an open place. ${ }^{5}$

The beginning of Portuguese settlement in Mylapur is very contradictory in nature. Mundadan pointed out that there was no Portuguese settler in Mylapur till 1519. ${ }^{6}$ Jeyaseela Stephen also supports that these Portuguese settlers came in the year 1519 to reside there for the first time. ${ }^{7}$ However, H.D. Love has point that the Portuguese settlements of San Thome could not have been form earlier than 1522. ${ }^{8}$ When the Portuguese started settling down in Mylapur, the local believe the place felt secure because they could get protection against the pirates who had been constantly harassing the native ships. ${ }^{9}$ They further saw the arrival of the Portuguese the fulfilment of the prophecy made by their ancestors that there would come a time when white people would arrive and give the black man food to eat and clothes to wear and that when the sea approached the house that would be the end of the world. Whether the prophecy came from St. Thomas the Apostle himself or from some ancient people and whether the people of the place believed it or not, it gave an added boost to the morale of the Portuguese who decided to settle down in Mylapur. ${ }^{10}$

Once they had established themselves along the Coromandel Coast, one can conjecture that the Portuguese casados and fugitive soldiers (who probably took wives and considered themselves as casados as well) opened trading with Bengal and the countries to the east, namely Arakan, Pegu and even Tenasserim, near present day Thailand. Bengal and Coromandel were famous for their cotton clothes of all varieties and grades, while the countries on the eastern side of the bay possessed a climate unfavourable for cotton growing and depended on India to supply them. In return, the casado traders from Coromandel could obtain gemstones, silver and spices. Thus, the next logical places for Portuguese settlement were in those areas themselves where they had been doing business, though it is far from certain that all the Portuguese who settled in Bengal had first been in Coromandel. The Hindu merchants from the same Coromandel region had not completely pre-empted this trade is perhaps explained by the Hindu tendency around 1500 to regard sea voyage as defiling, though there were many exceptions to the rule. At any rate, the casados in Coromandel were in the best trading

\footnotetext{
${ }^{5}$ Mundadan, A. M, "The Portuguese Settlement in Mylapore and Traditions about the Indian Apostolate St. Thomas and the tomb of Mylapur." Both in the, Indian Church History Review, Vol. III, No. I, June 1969, pp.103-115, \& pp. 5-19.

${ }^{6}$ Mundadan, A. M, “The Portuguese Settlement in Mylapore," Indian Church History Review, Vol. III No. I

June 1969. See also his book on the, History of Christianity in India, vol-I, p. 424.

${ }^{7}$ Stephen, S. Jeyaseela, (1989), Portuguese in the Tamil Coast, p. 242.

${ }^{8}$ Love, H.D. (1996). Vestiges of old Madras, vol.1, p. 289.

${ }^{9}$ Stephen, S. Jeyaseela, (1998). Portuguese in the Tamil Coast, pp. 242-243.

${ }^{10}$ Mundadan, A. M, (1984). History of Christianity in India, Vol. 1, p.425.
} 
position, and the opening of Bengal to Portuguese residence provided an excellent opportunity for those who had not struck permanent roots. ${ }^{11}$

The discovery of the tomb of St. Thomas had an impact of some significance on the nature of private Portuguese settlement. According to Subramanyan, this was manifest in the increasing tendency for respectable Portuguese to settle there, at the Sainted Apostle after having served the crown for some years in Asia. These settlers in contrast to the earlier breed of Portuguese at Pulicat, were able to seek for themselves a sort of special status, legitimising what had earlier been regarded as a disloyal act, that of putting personal gain and private commerce over the service of the crown. ${ }^{12}$ When we look at the different angle, the Portuguese settlers in San Thome were mostly deserters from the garrisons like Malacca and Cochin, renegades and disadvantage outlaws, ${ }^{13}$ as well as few people whose status was more legitimate in the eyes of the Portuguese official. For example, Miguel Ferreira, Alburquerque's ambassador to the Persian court, settled at San Thome in the 1530s and 1540s with mestico, trading and maintained a fleet of his own ships as well as holds the post of captain of the coast on more than one occasion. ${ }^{14}$ These soldiers turned merchants especially desired to participate in maritime trading activities, as there was surplus commodity available in Coromandel, particularly rice and textile and a potential market in the South East Asia, where there is deficit in these commodities.

According to Stephen, the Portuguese in San Thome were a heterogeneous community. Most of them were deserters or renegades, some were political exiles, homicides etc. These were the people who did not pay any heed to the dictates of their conscience and led a life of unbecoming of a Christian. Most of them had left Portugal for years, deserting even their wives. It is possible to surmise from this that the Portuguese society was a mixture of different elements and they were virtually free from any control. Neither the Portuguese Governor nor the captain exercised any authority over them. ${ }^{15}$ Moreover, its officials did not follow the usual pattern of salaried, three-year nomination but were unsalaried and named for irregular terms, sometimes even for life. There was no convoy or port duty system, and in almost all instances, its inhabitants did almost exactly as they pleased all time. H.D. Love states that, "no revenue accrued to the king of Portugal from San Thome as all sources of revenue belong to the lord of the soil. As a result, the Portuguese did not establish any administrative machinery at San Thome. Only two officials received a pay of 2000 cruzados annually from Goa, the Captain and the Bishop. In former times the lord of the soil used to pay the captain a gold pagoda per day. But the current arrangement, which was far less profitable, was that of the payment, half the revenues received from the sea-customs dues."

Indeed, for years on end the most important city of San Thome had no captain at all. The colonial inhabitants having only infallible ties were the Catholic Church and the Portuguese Padroado, the royal responsibility for the church and its mission within the area of Papal donation. Partly as a result of this lawlessness, Garcia de Noronha (1538 - 1540), the viceroy of Goa ordered the deportation of the resident of Mylapur to the west coast of India. He sent Mauel de Gama (Captain-Factor and the successors of the first captain Father Manuel de Frairs) with powers to deport them and rage down the settlement. Manuel de Gama managed to bring some of the resident to Kochi. ${ }^{17}$ Moreover, it was due to the viceroy's keen interest to develop the Portuguese settlement on the west coast, as the number of the Portuguese in India was too small and do not want to get scattered everywhere that prompted such a move. Dom Costantino Braganea, the later viceroy also followed the same policy to bring back the Portuguese to the west coast and he too was determined to prevent the

\footnotetext{
${ }^{11}$ Winius, George D, (2001), Studies on Portuguese Asia, 1495-1689, pp. 278-80.

${ }^{12}$ Subramanyam, Sanjay, (1990). The Political Economy of Commerce, p.106.

${ }^{13}$ G.V. Scammel,"European Exiles, Renegades and Outlaws and Maritime Economy Asia,"1500- 1750, Modern Asian Studies, 1992, 24.4. p 641-661. and Maria Augusta Lima Cruz, " Exile and Renegades in early sixteenth century Portuguese India,” The Indian Economic and Social History Review, 23. 3. 1986, p. 249- 261

${ }^{14}$ Subramanyam, Sanjay, (1990). Emprovising Empire, p.52.

${ }^{15}$ Stephem, S. Jeyaseela, (1997). Coromandel Coast and its Hinterland, pp. 182-183.

${ }^{16}$ Love, H. D, (1996). Vestiges of old Madras, Vol.1, p. 291. see also Subramanyam, Sanjay, (1990) The Political Economy of Commerce, p. 52.

${ }^{17}$ Stephen, S. Jeyaseela, (1998). Portuguese in the Tamil Coast, p. 243
} 
Portuguese stragglers to settle down at San Thome but the Portuguese refused to obey the order from the viceroy. ${ }^{18}$

If there is any reason why Mylapur was chosen as a particular target it was because it was the only settlement in the Bay of Bengal which had any legitimacy beyond mercantile self-interest, the legitimacy derived, of course, from the fact that the Apostle St. Thomas's tomb was located there. D. Garcia's representative, Manuel de Gama, was instructed to go to San Thome with an armada, to dismantle the settlement and perhaps to bring away the relics of the Apostle. It would appear that the Viceroy like his successor, de Brangaca in the early 1560s, miscalculated in respect of the Coromandel Coast.

By the late 1530s the Coromandel settlements of the Portuguese, Nagapattinam to the South, Mylapur and Pulicat to the North already had men of influence and prestige residing in them; entrepreneurs like Miguel Ferreira (1466-1548) were celebrated figures in their lifetimes, and capable of holding their own correspondence with the court of Portugal. With friends in the court and among the powerful and entrenched casados of Cochin and Goa, dislodging Ferreira was not an easy matter. Thus, Da Gama's expectation failed miserably. On the other hand, flourishing trade between Coromandel, Sri Lanka, Bengal, Burma and the Malay Peninsula ports continued to provide a reasonable return to the Portuguese settlers in Mylapur. ${ }^{19}$ Thereafter, the settlers seemed to have won their case partly, because San Thome got its own appointed captain after 1542, or thereabouts and despite a few bad ones, most appear to have been contented. One can only conclude that the Estado da India finally decided that further pestering of the distant Portuguese settlers was not worth the expense and troublesome.

It is evident that the Portuguese on the Coromandel lived more or less outside the Portuguese domain. As they received no pay or support from the Portuguese king, they showed a tendency to remain independent. They disapproved any attempts by the crown to control their activity by appointing captains at various ports in Coromandel. As early as in 1537 the private Portuguese traders wrote to the king to the effect that a permanent captain could be appointed in future from among themselves as most of the captains appointed by the Governor were generally young fidalgos whose primary concerns was to make use of their three year term to enrich themselves as quickly as possible.

Manucci, who visited San Thome in the end of the seventeenth century, gives us in detail on the living condition of the Portuguese in San Thome. He mentions some of the feud between rival factions. According to Manucci the residents of San Thome face many oppressions and much injustice. They slew one another; they dug and fortified trenches in the streets, furnishing them with cannon. Both sides had their rendezvous, and spent much money in maintaining soldiers. If anyone passed carelessly down the street, they just shot him with their matchlocks. They obtained reward for their evil deeds paying no respect even to the Holy of Holies, shooting down men during religious procession owing to the risings tension in the town the convents and churches were barricade. The friar was volunteers to fetch water for the weaker party. ${ }^{20}$ Besides the quarrel, merely to see the laming innocent person who was passing in the street, the master ordered his servant to fire his gun and finish off the laming person. ${ }^{21}$ This order was given when he was praying and rosary at his hand. The servant fired and reported to his master that the passerby was wounded in spite of saving order to fire another bullet to finish off the man. ${ }^{22}$

\footnotetext{
${ }^{18}$ Stephen, S. Jeyaseela, (1998). Portuguese in the Tamil Coast, p. 243-244.

${ }^{19}$ Subramanyam, Sanjay, (1993). The Portuguese Empire in Asia, p. 89.

${ }^{20}$ Irvine, William (trans.), (1990). Storia Do Mogor or Mogul India, 1653-1708, by Niccolao Manucci, vol. III, p. 119.

${ }^{21}$ ' $\mathrm{He}$ ' the name of the person is not mention. Irvine, William (trans.), (1990). Storia Do Mogor or Mogul India, 1653-1708, by Niccolao Manucci, vol. III, p. 119.

${ }^{22}$ Irvine, William (trans.), (1990). Storia Do Mogor or Mogul India, 1653-1708, by Niccolao Manucci, vol. III, p.119.
} 
Further trouble occurred under the viceroy D. Constantino de Braganca. The trouble occurred in 1559 due to religious intolerance of the Portuguese priests in the nearby San Thome. These priests before rising an alter to offer their sacrifices to Almighty God, destroy the Hindu temple near the village of San Thome. These angered the Brahmins who complained to their king Aravidu Ramaraja to give justice to his subjects. Subsequently, the king besieged San Thome. However, Meersman argued that the occupation of San Thome by Ramaraja was due to his need for money. Since Ramaraja had maintained large troops, it compels him to attack at any given opportunity. The casados were reluctant to come to the aid of San Thome as Ramaraja was the lord of the place. Instead, they went to Ramaraja's camps with a present worth 4000 cruzados. However, he proved difficult to satisfy and demanded 100,000 pagodas as compensation for destruction of their temples. ${ }^{23}$ The king took 25 casados as hostages and carried away the relics of St. Thomas. However, on the way back to his capital he changed his mind and sent back the relics to Mylapur. The hostages were release after having paid 50,000 pagodas and promising to pay the remainder. ${ }^{24}$

It is not certain whether the attacks on the Portuguese settlers experienced periodically in their locality around the Coromandel were directly related to the proselytization or not. The Hindus of South India were still disrupting when a Paravas community converts en masse to Christianity. On the other hand, the king of Vijayanagar also could not forget what the Portuguese had done during the famine in 1540s. In 1540, the Coromandel Coast witnessed severe famine. The people from the surrounding areas migrated in large number to escape from the rigours of famine. The Portuguese in San Thome showed generosity during these moments of hardship and King Achytadevarya was grateful to the Portuguese. He even sent a letter of appreciation to the captain of San Thone. Indeed, this may be the reason why King Ramaraja suddenly holds back to attack San Thome. ${ }^{25}$

In the course of time the condition of the famine improved and the Portuguese population increased as more people from the west coast migrated. The population of San Thome during 1538 was sixty families, in 1543, it reached 100 and in 1545 it was around 500. Francis Xavier when he visited in 1545 the number of casados was more than 100. After a year that is in 1546, there were 500 Portuguese in San Thome with their slaves. By the year 1559, the populations of San Thome rose to 2000 including the Portuguese and natives. In 1563, there were as many as 4000 Christians besides sixty war veterans with their families.

The port of San Thome faced the sea on the west. Most of the houses were located facing the sea, and was surrounded by mud walls. ${ }^{26}$ The settlement spread to its neighbouring regions known as 'Little and Big Mounts', places, according to tradition, hallowed by the life of the Apostle. The Little Mount, which was later known also as the Mount of Our Lady of Health and Calvary, attracted the attention of the Portuguese especially for the cave where many crosses were found. The Portuguese settlement in these two mounts began in 1523 and among them; Diego Fernandez was one of the first settlers. He raised a monument there in the same year in honour of the Mother of God. While foundations were dug for new building, many ruined foundations of earlier buildings were discovered along with many crosses. Among them, the famous miraculous cross was discover in $1547 .^{27}$

Even at this early stage their settlement in the area, the Portuguese were careful to separate their section of the settlement in the port from the natives' settlers. The houses of the Portuguese were roughly constructed and did not use of lime and mortar until in $1590 \mathrm{~s} .{ }^{28}$ The native quarter, inhabited by the Hindus, is called Mylapur. An officer (Havaldar) from the king of Vijayanagar was station there. This official looked after the affairs of the Hindus, administered justice and leased out the right to collect port tax. On the Portuguese side, the settlements were known as San Thome. San Thome

\footnotetext{
${ }^{23}$ Meersman, Achilles, (1962). The Franciscans in Tamiland, pp. 9-10.

${ }^{24}$ Subramanyam, Sanjay, (1990). Improvising Empire, p. 58. See also J, Thekkedath, (1969). History of Christianity in India, Vol.II, p. 201.

${ }^{25}$ Stephen, S. Jeyaseela, (1998). Portuguese in Tamil Coast, p. 243

${ }^{26}$ Schurhammer, Georg , (1977). Francis Xavier,His life, His time, p. 598

${ }^{27}$ Stephen, S. Jeyaseela, (1998). Portuguese in Tamil Coast, p. 243

${ }^{28}$ Subramanyam, Sanjay, (1990). The Political Economy of Commerce Southern India, p.105.
} 
replaced Mylapur in the Portuguese official records from 1545. ${ }^{29}$ The Portuguese had a captain appointed by the king of Portugal. He issued cartazes to the merchants who voyage long distance trade with various ports, especially trade in the South East Asia. ${ }^{30}$ While in theory the captains were appointed by the king in practice they materialize from the local Portuguese inhabitants and then were recognised by the king. They sometimes appointed for life but received no salaries. At times, there were no captains at all. ${ }^{31}$

The first Portuguese captain of the Coromandel Coast was Manuel de Frias, patron of the Viceroy of Goa, Dom Duarte de Meneses, appointed in 1521. The captain was station at Pulicat, and held the post for a period of three years. He had jurisdiction over all Portuguese settlements on the coast with the aid of a small fleet, maintained at the expense from the crown and further issued cartazes to merchants that operated around Coromandal. The revenue that was generating by issuing these cartazes probably went to the captain as perquisite in addition to the salary paid to him by the crown. ${ }^{32}$ The issue of cartazes during this period had two purposes; to guarantee to the captains small revenue, and to ensure that no contraband goods particularly pepper, which is a royal monopoly was forbidden to carry or trade. ${ }^{33}$ The captain was appointing as the factor of the coast. He was also the administrator of the Portuguese people on the coast, with the title implying that he had control over the estates of the Portuguese who died on the coast as well as those temporarily absent from it. In the case of death, he was responsible for dividing the estate among the heirs or dispatching them in Europe. In return for the service, he was entitled to a share of the estate. Financially, this charge gave a great deal of power to its holder. ${ }^{34}$

Later the trading centre shifted from Pulicat to San Thome as the former incurred heavy trade losses and the Portuguese crown decided not to have a fort at Pulicat. The seat of the captaincy of Coromandel was therefore shift from Pulicat to San Thome when the next captain Miguel Ferreira took up his residence in 1530. ${ }^{35}$ In the 1540s, San Thome of Mylapur replaced Pulicat in importance. Moreover, as the Portuguese began trading with Malacca directly from San Thome, Pulicat was reduce to a mid point on the Malacca-Goa route, which suited the Portuguese very well but not the indigenous traders trading from Pulicat. Besides the new trade route, the established customhouse for the Coromandel merchants trading with Malacca was to pay the freight in advance and make their return voyage on the same ship in which they had sail out also favoured the traders based in San Thome. Since such facilities were made available at San Thome, they preferred to settle down at San Thome and trade directly with Malacca from there and abandon Pulicat. ${ }^{36}$ Thus, one would say, San Thome emerges finally from the "Shadow of Pulicat" and appears as a centre of commerce in its own right. $^{37}$

The people of San Thome never left the religious aspects of its life. It was one of the major significance to those who lived in San Thome. For instance, the feast of St. Thomas, in midDecember, had a numerous miracle stories associated with it and was consider very important for the Portuguese community. ${ }^{38}$ Within the town itself, the religious orders actively engaged themselves with the mundane chores. The Jesuits, for example, conducted Latin classes in the college they had constructed in San Thome, and they together with other orders (Franciscans, Augustinians,

\footnotetext{
${ }^{29}$ Stephen S. Jeyaseela, (1998). Portuguese in the Tamil Coast, p. 244. see also Medlycott, A. E. (1905). India and the Apostle Thomas, In Inquiry With a Critical Analysis of the Act a Thoma, p. 86.

${ }^{30}$ Mundadan, A. M. “The Portuguese Settlement in Mylapore,” Indian Church History Review, Vol. III No. I, June 1969. p.112.

${ }^{31}$ Pearson, M. N, (1987). The Portuguese in India. p. 84

${ }^{32}$ Subramanyam, Sanjay, (1990). The Political Economy of Commerce Southern India, p. 105.

${ }^{33}$ Stephen, S. Jeyaseela, (1998). Portuguese in the Tamil Coast, p. 244

${ }^{34}$ Pearson, M.N, (1987). The Portuguese in India, p. 84

${ }^{35}$ Stephen, S. Jeyaseela, (1997). Coromandel Coast and its Hinterland. p. 111.

${ }^{36}$ Stephen, S. Jeyaseela, (1997). Coromandel Coast and its Hinterland. p. 144.

${ }^{37}$ Subramanyam, Sanjay, (1990). Improvising Empire, p. 62.

${ }^{38}$ J.J. Campos had describe that the Portuguese in San Thome had full liberty to celebrate the feast in the same order and with the same solemnity as in Europe, but did not mention which festival, (1919). History of Portuguese in Bengal, p.168.
} 
Dominicans and Theatine) were involved in missionary activities especially among the fisher villages of the area. Sadly, the number of converts was very few; in a good year (1593 to 1594), it was just eighty. ${ }^{39}$

The Portuguese population of San Thome consisted mainly of deserters, renegades, political exile and fidalgos. They were mostly commercial minded and attracted towards the surplus commodities available in Coromandel, particularly rice and textiles. In the larger context neither the Portuguese Governor nor the Captain exercised any authority over them and were in fact, free to do one's own will. Under such condition, it was difficult to lead a peaceful life for any person. A remarkable incident happens in the 1590's when a certain man from a rich, powerful and well to do family kidnapped the wife of another settler, and held her captive within his house. Despite the intervention of both the religious orders from the town, he refused to relent. The husband of the victim tried various means to resolve the matter, and even wrote to Goa but to little avail. Eventually, the Magistrate, Lopo Alvares de Moura, was force to take an extreme step. He invited the kidnapper to his house under false pretexts, and with the complicity of the Jesuits, strangled him with a garrotte. Later they hung him with a rope from an improvised gallows to give the affair an appearance of legality. It is report that following this deed Moura took to his heels for fear of the relatives who were many and very powerful. Predictably, the next day his house was attack and destroyed by the irate relatives. $^{40}$

Father Navarrete, had also recorded that the inhabitants of San Thome came to be very rich and powerful and consequently grew very proud. He noted 'one woman, ${ }^{41}$ that she grew of that height, that when she went to Church attended by many women slaves one went before with a censor performing her with burnt sweets, can any madness be greater! She had, say they, so many St. Thomas (they are crown-pieces with the effigies of the Apostle) that she measured them by the peek.' ${ }^{42}$ Manucci conclude that 'when the woman', mentioned above, 'was about to die, she became so miserably poor that she did not have even a piece of cloth to make a shroud, and at her burial she was wrapped in a reed mat. This is the fate of her whosoever forgets the creator.' ${ }^{43}$

Navarrete, an orthodox Friar finds it very difficult to digest when he experience his fellow priest in San Thome who were more incline towards the worldly affairs. He noted that "what follow is worse, many told me (would to God it were a lye), and I had not heard it that catholic men were pimps to catholic women with Mahomatans (Muslims) and gentiles (Hindus). A beautiful and honest maid was forced out of her father's house, and deliver to a Mahomatan. The king of Golconda has a concubine to this day, the daughter of a Portuguese." Further, he adds, "the procession of the holy week in the city of St. Thomas, some Portuguese, though in the presence of Heathen (Hindu), drew their swords one against another, there's devotion and good example for you." ${ }^{4}$

Manucci's account provides some information of San Thome during those days when he stayed there. He narrates that a, Portuguese priest from Manila, a good theologian, name Luis Pereyra. He brought with him some money for helping his parents, who lived in Daman. About the same time there was a newly man arrived from Portuguese named Martin de Lemos, who had quitted Portugal because of his being a lawbreaker and highway robbery. He had no money for his own and so begged help from those who governed. The reply they gave was that he might search for his expenses wherever they were to be found. Finding an excellent opportunity one Sunday at seven in the morning he (Lemos) went into the house of Father Luis Pereyra, pointed a pistol at his breast, and ordered four Kaffirs (a black African slave) to bind him. Breaking the box, he robbed all that was with him and went to Madras.

\footnotetext{
${ }^{39}$ Subramanyam, Sanjay, (1990). Improvising Empire, pp. 63-64.

${ }^{40}$ Irvine, William, (trans.), (1990). Storia Do Mogor or Mogul India, Vol. III, pp. 246-249.

${ }^{41}$ He did not mention the name of woman, Cummins, J.S., (ed.), (1962). The Travels and Controversies of Friar Domingo Navarette, Vol. I, p. 301.

${ }^{42}$ Cummins, J.S (ed.), (1962), The Travels and Controversies of Frair Domingo Navarrete, 1618-1686, p.302.

${ }^{43}$ Irvine, William, (trans.), (1990). Storia Do Mogor or Mogul India, Vol. III, pp. 118-119.

${ }^{44}$ Cummins, J.S (ed.), (1962). The Travels and Controversies of Frair Domingo Navarrete, p.301.
} 
At that time, Manucci was in the churchyard of the Church Madre de Deos on his way to Mass, after hearing the incident some foreigners wanted to run on the spot to help the Father. However, Antonio Palha, one of governed, warms him and excused from taking those troubles. He and the rest went leisurely to their houses giving time for the robber to carry out his attempt and get away in safety. Later Palha sent first to see if the looter had already gone, and a report was brought that he was now a long way off. After obtaining this information, Palha came fully armed, shouting along the street for everybody to come and help father Luis Pereyra. They all went to him and found him tied to a pillar. They untied him and tried to console him by saying they had made all possible haste to assist him, but to come sooner was impossible, they were being at mass. ${ }^{45}$ Certainly, it reflects the negative sense of law and order. The captain was unable to look after his subject and fail to give justice to the innocent settlers.

Even the life of a simple family was so vituperate. Deep down in every family there are many related story, which the society cannot accept. Manucci in his book narrates, a man married to a rich and influential woman of good connection slept with a girl servant, but when his wife found the girl conceiving, she killed her and after mutilating the body ordered it to be buried in the garden behind the house. The flesh removed from the body was cook in her own presence and presented the dish to her husband who ate and praised it for its exquisite taste. His wife in a fit of anger flung the dish in his face and abuse him by saying it was not enough to have enjoyed her while she was alive; even in death she was of good savour. Her anger overflowing, she gave her husband plentiful abuse, and quitting the house, went to live with her relatives for the rest of her life, she never meet her husband. ${ }^{46}$

Leaving aside the above statement, a factional fight was common in the street of San Thome. There were clear factional strife among the casados, and the power of different factions and their leader was partly determine by their connections with the local political structure, which in the early seventeenth century was made up by a set of bandleaders. The captains were always their first priority while choosing their own leaders. With this situation, most of the time the inhabitant of San Thome did not recognised the captain chosen by the Viceroy from Goa. The benefit of electing among the competing merchants as a captain representing their side was the opportunity for concession voyage. Thus, the resident of San Thome always complaint about the captains appointed by the Viceroy whose primary concern was to make use of their three year term to enrich themselves as quickly as possible.

Simultaneously, there was powerful clan-based factions led by the Kaposos and a certain man name Antonio de Sousa Pereira, the latter also deriving support from local rulers, in return for rendering them military services. Sanjay Subrmanyam argued that such clan conflict did not mean San Thome was on the decline by this period. Of course, it is true that factional strife in the town was on the increase but this was not of a level to fundamentally affect the long-term prospect of the town. This would be evident from the fact that in 1600 the Portuguese settlement of San Thome de Mylapur was at the height of its commercial prosperity and importance. Few residents there could have foreseen its lamentable state a mere three decades later. ${ }^{47}$

The heydays of these communities were from 1570-1610s, and it corresponds closely with that of the private trading in the Estado's west coast heartland. The private trading on the west coast was carry by a mixture of Hindu vanias and other traders and Portuguese casado families, themselves of mixed European and Indian ancestry after the first generation, and thus a part of the general trading picture was set. Seeing that both Gujarati and Konkani traders traditionally had close trading links, both in cotton textiles and foodstuffs from Coromandel and Bengal, and that Estado da India initially derived much of its foodstuffs from there, it is more likely that both groups of merchants on the east and west coasts shared a related and even integrated prosperity. ${ }^{48}$

\footnotetext{
${ }^{45}$ Irvine, William, (trans.), (1990). Storia Do Mogor or Mogul India, Vol. III, pp.123-24.

${ }^{46}$ Irvine, William, (trans.), (1990). Storia Do Mogor or Mogul India, Vol. III, p. 107.

${ }^{47}$ Subramanyam, Sanjay, (1990). Improvising Empire, pp. 66-67.

${ }^{48}$ Winius, G. D. (2001). Portuguese in Asia, p. 274.
} 
San Thome of Mylapur was raised to the status of a cidade in 1609 through a royal order from the King of Portugal notified subsequently by the Viceroy of Goa. A Camara Municipal (Municipal Council) too was brought into existence. The Municipal Council was invested with the power to frame rules to regulate the civic life. It was also ordered by the King of Portugal that only local laws, regulations, customs and conventions should be observed with regards to matters relating to the indigenous people. The natives were permit to live without any distinction. As for others, it was stipulated that there should be a civil registry in San Thome so that none could pretend to be a subject of any other ruler even though he may be a fraud or a foe of the Portuguese. The census was counted for the first time in $1614 .^{49}$

The coming of the other Europeans, the Dutch and the English posed a threat to the Portuguese, especially from the former, in the Coromandel. The residents of San Thome felt considerably necessary for fortification. However, to carry out such a huge project they needed large financial resources. Neither the Viceroy of Goa nor the King of Portugal provided the money required for carrying out the fortification. Hence, the responsibility of mobilising the funds came to rest on the shoulders of the rich merchants. This issue was settled by granting the privileges for undertaking commercial voyages from Coromandel to South East Asia. The King of Portugal directed the Viceroy of Goa in 1609 that the profit from three voyages to Malacca and three voyages to Pegu to be given to the Municipal Council for the construction of the fort around San Thome. The inhabitants of San Thome in a letter to Philippe II (1598 - 1621), the King of Portugal, on 7 March 1613, demand additional financial help to fortify San Thome. They further suggested that a customhouse, on the model of the King of Vijayanagar, could be established in San Thome to collect four percent duty on all commodities. The suggestion was granted and with the allotted funds, the fortification begins. But the Vijayanagar ruler King Venkata II (1613) invaded San Thome since permissions was not sought to built a fort. It should be note that such fortification needs authorization and approval from the local ruler.

Thereafter, the work commenced only after the death of King Venkata II in October 1614. Further, on 2 May 1620 money was sanction from the treasury of the King of Portugal. The Captain was notified on 12 September 1620 to seek the assistance of expert engineer to execute the work with the help of the local workers. This process of extending Portuguese sovereignty in the area was possible because there was no effective ruler at that time in the region. ${ }^{50}$

The reality in the Portuguese settlement seems to be different after the death of most successful ruler of Vijayanagar Ramaraya in the context of Coromandel region. His successor Venkatapati Raya or Venkata II (1586-1614), a monarch who confronted with adverse circumstances to his recalcitrant vassals and the threatening power of Bijapur and Golconda to the North, managed to preserve a certain degree of stability within the empire. Nevertheless, we also know that before his rule, in the battle of Talikota in January 1565, the power of Vijayanagar had virtually come to an end. Due to the prevailing fragile political situation, King Venkatapati Raya transferred his court to the fortified centre of Penugonda, Southeast of the old capital of Vijayanagar. However, with this transfer the formal control over the Western extremities of their empire, particularly the Kanara coastal plain, dwindled. Further, between 1570 and 1610, control over the Southwest of the empire was progressively given up on account of the rise of the quasi-independent state of Mysore.

The same process occurred, though to a lesser degree, to the Southeast of Coromandel with the growing assertiveness of the principalities of Madurai, Tanjavur and Senji. ${ }^{51}$ In its place, there emerged regional centres of political power. Furthermore, in the 1590s Venkata II again shifted the

\footnotetext{
${ }^{49}$ Stephen, S. Jeyaseela, (1998). Portuguese in Tamil Coast, pp. 245-246.

${ }^{50}$ Stephen, S. Jeyaseela, (1998). Portuguese in the Tamil Coast, pp. 246-249.

${ }^{51}$ Under Senji territory the two ports San Thome and Pulicat were located.
} 
court from Perugonda even further east. This created a system of twin courts at Velur and Chandragiri, which lasted until the effective dissolutions of the empire in the 1640s. ${ }^{52}$

Simultaneously, the political rupture created a power vacuum in the region. At the same time, the Sultan of Golconda, who wanted to grab the opportunity, resulted in putting pressure on the Portuguese settlements at San Thome. The Sultan of Golconda desirous of controlling the town from the Portuguese rather than letting off in the hands of the Dutch who have already established their factory at Pulicat in 1609 finally managed to siege San Thome in 1662. The seige led by Mir Jumla brought the country in total chaos. "No less then 3000 people died since September last, in Pulicat, as report said 15,000 and San Thome no less then these." ${ }^{\text {33 }}$ Thus, San Thome was completely overrun by Golconda in May 1662.

The Dutch Chief at Pulicat on his own accord blocked San Thome by sea, and with no option, the Portuguese surrender to the Golconda troops, who at once strengthen its fortification and posted a strong force there. Most of the Portuguese took refuge in Madras to the annoyance of the Golconda authorities that threatened reprisals, but the English reply that shelter could not be refused to Christians. The Dutch felt much aggrieved at their failure to secure a footing in the city. ${ }^{54}$

The French again captured San Thome exactly after 11 years. The French fleet under Admiral de Haye appeared on the Coromandel Coast in July 1672 and captured San Thome from Golconda. The French occupation of San Thome, which lasted a little over two years, was a long period of belligerence. It divides itself into two active sieges separated by three months of passivity. From the 30 July 1672 to the 10 March 1673, the force of Golconda attacked alone but from the 30 June 1673, the fortress was blockaded and attacked by the combined strength of the Golconda and Dutch until it was starved into capitulation on the 24 August $1674 .{ }^{55}$

When the ruler of Golconda recovered San Thome with Dutch assistance, there was a great pressure by the Dutch and English to destroy the port town. Neither the Dutch nor the English wanted to see another port so near to their chief settlement to attract trading communities from Europe. The Dutch believed that the best way they could protected was to approach the Golconda court to favour the destruction of San Thome. The Dutch selected William Lard Hartsinck, Dutch Chief of Golconda (1663-1677) to represent their case. The latter emphasized, particularly to the Minister Madanna, that the razing of San Thome was not only in the material interests of the kingdom but was also a necessary defensive measure. ${ }^{56}$ The minister was known for his parsimony and the Governor struck at his weak spot when he pointed out how expensive it would be to demolish the constructions at San Thome. When the orders were reiterated, however, the Governor had no alternative but to obey. The beautiful cathedral that was name and consider as one of the best monuments of early Christianity in idea was thus destroyed. The Dutch even went so far as to offer to help in this demolition proceeding. It almost seemed the Dutch could not wait to see the town completely razed. The English were also utilizing the material from San Thome to build themselves the beautiful houses, which is still not yet seen at Madras. While refusing any overt help in the demolition proceeding at San Thome, the English factors Langhorn provided gunpowder for blowing up the walls and allowed the residents of Madras to bring away stones from there. ${ }^{57}$

San Thome did not remain the same even though the rulers of Golconda allowed to return in 1676. The real problem was, persuading the Portuguese residents in other parts of Coromandel to return to the folds and once again become residents of an official of the Estado da India, which the English neighbours totally object it. At the same time, the Portuguese rather consider more secure

\footnotetext{
${ }^{52}$ Sastri, K. A. Nilakantha, (1958). A history of South India from Prehistoric times to the fall of Vijayanagra, pp. 297-350,

${ }^{53}$ Foster, William, (ed.), (1914). The English Factories in India, 1646-1650, p.70.

${ }^{54}$ Foster, William, (ed.), (1923). The English Factories in India, 1661-1664, p.146.

${ }^{55}$ Love, H. D, (1996). Vestige of Old Madras, p. 316.

${ }^{56}$ Varadarajan, Lotika (ed.), (1981). Memoris of Francois Martin, Vol. I, Part. II, p. 496.

${ }^{57}$ Varadarajan, Lotika (ed.), (1981). Memoris of Francois Martin, Vol. I, Part. II, pp. 506-09.
} 
working under the English flag. Most of these Portuguese who saw the coming of other European's were now convince that the glory of the Portuguese flag was crumble and it will be wiser to switch on the stronger side. Thus, it can be conclude that they were main benefactor in the sixteenth century as they were the first European nations to reach and later dominate the exclusive spice trade but in the seventeenth, it was not there century anymore.

\section{Nagapattinam}

The port of Nagapattinam flourish under the Cholas in the eleventh and twelfth centuries and the Chinese merchant visited and they called it na-kia-po-tan-na. ${ }^{58}$ It is probable that the first Portuguese to settle at Nagapattinam did so in the mid 1520. In 1533, there were roughly around thirty Portuguese at Nagapattinam, later in 1540s it increased nominally to a hundred, mostly private traders interested in the rice trade to Sri Lanka. A Captain was appointed to look after the settlement. In the 1530s and 1540s, the Captain complaint that the spread of the Portuguese along the coast made difficult to control by a single authority as most of the time the Captain was in the Northern Coromandel. Persistent complaints repeated through the 1540s and 1550s finally had an effect at the close of the latter decade in 1560 when a decision was taken to divide the captaincy of Coromandel into two section; one would be resident at San Thome, the other at Nagapattinam. This modification was accompanied by several other changes in the administrative structure. Whereas the captaincy of Coromandel had carried a salary, and explicit naval functions, the new captains were devoid of salary and his activity on land were restricted. Moreover, whereas the earlier captaincy of the coast as a whole had carried with it a three-year term, the captains of San Thome was appointed for life, those of Nagapattinam continuing to hold three-year terms. The 1560's reforms seem to signal the shift in the balance of power between the captains (representatives of the authority of Goa) and the settlers over whom they exercised jurisdictions. The outcome was decline in status of the captains and rise of two important institutions based in the Coromandel settlements. First was the Santa Casa Misericondia (Holy house of Mercy), a corporate body, with the charge of managing the liquidations and despatch to their heirs of the estates of deceased residents. This task had earlier been with the captains of Coromandel. The other corporate body of importance is eleitos, which was clearly modelled on the municipal chambers that regulated corporate life in the Portuguese cities. This unofficial council consisting of five members was formed by the casados of Nagapattinam to administer the affairs of the growing town. Its members were powerful traders who set together and settled disputes among the local residents. ${ }^{59}$ However, Nagapattinam was not recognised in the formal juridical structure of the Estado da India as a cidade, the eleitos too did not enjoy the privileges of the camara municipal. ${ }^{60}$

This curtailment of the captain's authority may suggest that these posts had no real worth. However, not the least, the captains in fact has two source of income. The first seem to be the concession system of voyages introduced into Asia by the Portuguese crown. In case of Nagapattinam four concessions voyages were granted such as to Kedah, Vjangsalang, Mergui and Martaban. In each of these voyages, the holder of the concession enjoyed the sole right in a given trading season. Though the Portuguese Crown could in theory grant these four voyages to anyone but in reality it became (from the 1570's) an implicit perquisite of the captains of Nagapattinam. ${ }^{61}$ A second source of income for the captain was a grant from the villages around the town from the Nayak. They also seem to have received certain privileges in respect of customs payment. The revenue from the villages was worth some 1,400 xerafins annually, and the custom privileges valued at around 200 xerafins annually. ${ }^{62}$

Overall, the concession was notoriously problematic. There were numerous claimants whose claims have to be chronologically arranged so that precedence was assured to the one with the earliest date of royal grant. On some occasions, from 1585, the captain of Nagapattinam successfully used himself for one or the other voyage originating from that port as a perquisite in the end of the $16^{\text {th }}$

\footnotetext{
${ }^{58}$ Stephen, S. Jayaseela, (1997). Coromandel Coast and its Hinterland, p. 111.

${ }^{59}$ Stephen, S. Jayaseela, (1997). Coromandel Coast and its Hinterland, p. 237.

${ }^{60}$ Boxer, C. R. (1965). Portuguese Society in the Tropics. The Municipal councils of Goa, p.

${ }^{61}$ Subramanyam, Sanjay, (1990). Improvising Empire, pp.73-74.

${ }^{62}$ Subramanyam, Sanjay, (1990), Improvising Empire, p.74.
} 
century. The Estado put a pressure to tighten up the concession voyages. Customs at Malacca were raised, and an export duty levied on goods destined for Coromandel, where earlier only an import tax had existed. Even the ships coming from Nagapattinam to Negombo were told to pass through Colombo and pay duties there. This rash of ambitions legislation, implying as ever-greater set of claims backed by stagnant machinery for enforcement could only have widened the gap between legislation and reality. The breakdown of the concession system begins with the Dutch Company participation on the Portuguese profited trade mainly between the San Thome and Malacca. Those who suffered were the persons who had freighted spare aboard their ships.

The system of concessions, in theory meant only the concession holder was entitled to make this trip, usually in a large carrack laden from San Thome. As early as the 1580's when Malacca was desperately short of food supplies, exceptions had been made, and the occasional small craft from Nagapattinam, laden with rice, was permitted to go to Malacca. However, for such extraordinary circumstances a licence had to be sought (probably by the Malacca Camara) from the viceroy for the purpose. After 1600, when the trade between San Thome and Malacca became irregular Nagapattinam shippers began to encroach on this trade.

In October 1606, the Dutch Company vessels captured a large ship called Santo Antonio, belonging to Andre Furtado de Mendonca, near Nicobar. The ship was on its way from Nagapattinam to Malacca, and had on board the captain of Chaul, Don Luis Lobo and two of his nephews, besides the captain Ambrosiso Serrao Pereira, carrying 800 khandis of rice and 290 bales of textiles. Besides the goods, 700 persons were found on board. In course of time, however, such trade was taken at askance since it went against the concessions systems, which would thus cease to have meaning. Consequently, in July 1611, the Viceroy Rui Lourenco de Tavora dissolved all such extraordinary licences and ultimately a warning was issued to Nagapattinam's settlers (on the basis of a complaint made by its captain Antonio Celho de Vilha), starting that only the concession holder could make the voyage to Tavoy and Martaban from Nagapattinam. All those who would contravene this order would lose the ships and all the goods involved. ${ }^{63}$

Nagapattinam had acquired some of the urban features during 1530 to 1570 's. This could be seen from the writing of Casare Federici. According to his account, the Portuguese settlement that was very close to the sea was very big. ${ }^{64}$ A market place had taken shape within a distance of just about one league attracting a large number of merchants. The Portuguese town lay in the elbow or semicircle to the North of the bend in the river surrounded by it on three sides. To the North, where the Portuguese town ended, there began the native town; the southern limit was roughly demarcated by the Nilayadakshi Amman Temple and overlooked the sea on the eastern side. While the Hindu settlement were known as Papancheri, and Muslims were called Nagure, lying eight kilometres to the North. ${ }^{65}$

Francis Xavier who visit during 1545, witness Nagapattinam as a flourishing commercial port. As he described that, the harbour was the best along the entire Coromandel Coast, which was otherwise poorly provided with them. More than seven hundred sailing vessels were frequently docked at the same time on the river. Every year these vessels carried more than twenty thousand measures of rice (the Portuguese measure Moio held 752 quarts; 20,000 measures thus corresponded to same 470,000 bushels) from here to the western Coast of India. The trade here attracted merchants from all parts of India as well as from Pegu, Malacca and Sumatra. The quarter of the Moors and Portuguese adjoined the native city inhabited by Hindus. The houses were built of clay and covered with palm leaves since the lord of the land would not allowed private house to be built on stone. From the harbour, it could be seen rising up over the low roofs of the Portuguese settlements. ${ }^{66}$ Along with this, there existed large number of religious institutions both within the town and around it. Indeed,

\footnotetext{
63 Sanjay Subramanyam, The Political Economy of Commerce Southern India, pp.200-2001.

${ }^{64}$ Stephen, S. Jeyaseela, (1998). Portuguese in the Tamil Coast, p. 236.

${ }^{65}$ Subramanyam, Sanjay, (1990). The Political Economy of Commerce Southern India, p.196.

${ }^{66}$ Costelloe, M. Joseph, (trans.), (1977). Francis Xavier, His life, His time, 1541-1545, by Georg Schurhammer, p. 549
} 
the structure of the Portuguese quarter can be best defined in relation to these churches and religious centres. The earliest resident Christian orders at Nagapattinam were the Franciscans. The Jesuits appeared on the scene in the late sixteenth century. ${ }^{67}$

The Portuguese quarter were made up of relatively rude constructions mostly thatched with straw. The Churches of the Franciscans were impressive even in the 1570s. In the 1590s with the growing of economic prosperity among the casado community, the construction increased quickly. The town was re-fashioning with the characteristic red-tiled roofs in a classic Portuguese colonial style. Walls of stone whitewashed with lime and constructed with a quadrangular ground plan, around a central garden or arbour were prominent features of the town. ${ }^{68}$ As trade flourished, many Portuguese came from different places to take this opportunity and settle down to carried out their own trade. The settlement had sixty casados, 200 Eurasians and 300 Indian Christians in $1577 .{ }^{69}$ In the 1630's the number of household was estimate at around five hundred in the Portuguese quarter alone. Those deemed capable of bearing arms including mesticos and native Christians are estimate at around two thousands. By 1642, the number rose to 700 Christians, during this period Nagapattinam had the largest population compared to any other Portuguese settlement on the Coromandel Coast. ${ }^{70}$

The Portuguese residents of Nagapattinam had relatively a more peaceful life with less faction and disturbance throughout the sixteenth century. However, from 1601 the disorderly activities intensified in Nagapattinam and the king of Portugal gave a strict order and to punish all the culprits. The Viceroy of Goa also requested the judge to award severe punishment. It will be a worthwhile to mention some of the happening where Manucci has recollect in his book. 'In Nagapattinam there was a hounarble man named Joao Soares Coves, married to a beautiful lady and lead a happy life. He went out of the town and left his beautiful wife alone. There was another man named Christovao Pexoto, married, rich and very influential in the town. This man fell in love with the wife of Joao Soares Cove, sending her message that he wished to be her friend. As an honourable woman she declined to accept, and never came out for fear of this man. Christovao Pexoto forcefully entered the lady's house. Paying neither respect nor heed to the citizens, he mocked the magistrate and the inhabitants, and showed that he was afraid of no one. Joao Soares Cove returned from his journey and heard the entire happening. Seeing that he had neither strength nor could obtain satisfaction for the affront straight left for Goa. At Goa, he presented his case before the Viceroy Dom Filippe Mascarenhas (1646-51). On becoming aware of that man's insolent conduct, the viceroy gave an order to the magistrate to bring justice in one way or the other.

However, Christovao Pexoto sensing trouble escape from the town and settled in the country of a Hindu Prince not far from that place. Finding that they could not carry out their orders, the magistrate sent a present to the Hindu Prince, and a letter requesting him to hand over this insolent fellow in chains into the hands of the magistrate. Pexoto, instead of showing repentance and asking pardon, abuse Cove repeatedly, which angered Cove so much that he stabbed Pexoto with a pointed knife. After this was over, he hastened home to kill his wife. However, warned in time, she had fled to Tranquebar with her servant. For several days he went around all bloody, solely to prove that he wreaked vengeance for his wrongs. ${ }^{71}$

The structure of power within the Portuguese community, and its effect on the environment of the port left us more to interpret in the larger context. The constant factional fights among the Portuguese turn explosive with armed skirmishes on the streets, in which both sides would take recourse not merely to swords and staves but handgun as well. Wealth and power were not equally distributed even within the casado communities. Membership of the elite bodies (Eleitos de Negapatao), which comprised a group of five, and the governing council of the Casa de Misericordia,

\footnotetext{
${ }^{67}$ Thekkedath, Joseph, (1996). History of Christianity in India, Vol. II, pp.195-196.

${ }^{68}$ Subramanyam, Sanjay, (1990). Improvising Empire, pp 83-84.

${ }^{69}$ Winus, George. D, (2001). Portuguese in Asia, p. 92.

${ }^{70}$ Stephen, S. Jayaseela, (1998). Portuguese in the Tamil Coast. p. 241.

71 Irvine, William, (trans.), (1990). Storia Do Mogor or Mogul India, 1652-1708, by Niccolao Manucci, Vol. III. p. 112.
} 
were important prizes, and at the same time indicated the Pessoas principais (Leading lights) of the settlement. In the 1640s the names encountered on these two bodies (Eleitos de Negapatao and Casad de Miseri Cordia) include Joao Veloso, Joao Virira, Jao prossel de Darbudan, Manuel Goncalues Ferreria, Domingos Vas, and the brothers Cosmo and Manuel Ledo Lima. Migrants from other ports swelled these names encountered in a comprehensive list of the casados at Malacca in 1626, suggesting that migrants from different ports of the Estado swelled Nagapattinam's population. It can be also true the population is very few and the birth was not seen as an important determinant of status here. ${ }^{72}$

Thus, the Portuguese settlement at Nagapattinam was spontaneously shaped and nurture by the casado element in Portuguese Asia. Despite its non-official character, Nagapattinam was one of the most successful centres of Portuguese private trade in late sixteenth and early half of seventeenth century. In the early 1630s, when Conde de Linhares was the Viceroy at Goa, he repeatedly persuades the settlers at Nagapattinam to fortify their settlement. His intension was largely to protect against the Dutch and from the nayak of Tanjavur. The settlers refused as once Goa acquired a foothold it would not be long before a customs house would be set up in the name of the Iberian Crown. Nevertheless, the Viceroy's warning came true when Dutch under Van Diemen appear on the horizon. His intention was to hold the Portuguese settlement of Coromandel to ransom. To carry out his plan, Dutch armadas of five ships under the command of Cornelis Leendertszoon Blauw, arrived at Nagapattinam on 12 April 1642.

This sudden advance by the Dutch made the Portuguese to gather their strength but not in a large number. As most of them had not yet return from their trading voyage while others had fled the town. The Dutch demand 50,000 patacas (a gold coins) in ransom. The Portuguese pleaded that they were not the enemies of the Dutch as they are now subjects of John of Portugal and not Phillip of Spain. However, it did not much concern for the Dutch. After prolonged bargaining, the ransom was reducing to a quarter from their previous demand. However before this money could be gathered the nayak of Tanjavar entered the town and began skirmish with the Dutch. In the ensuring confusion, the Dutch retreated to their ships. Ultimately, the nayak handed over the port to the Portuguese again. ${ }^{73}$

The Dutch approach the nayak of Tanjaver, to evict the Portuguese from Nagapattinam who wanted his territory to be free from the clutches of foreign traders. The permission was flatly refuse by the nayak's, with no more option the Dutch returned to Pulicat. ${ }^{74}$ The Dutch believing that the Portuguese had treacherously called on the nayak for aid, in consequence the Dutch refused to release the Portuguese hostages whom they had seize and keep on their ship. The attack, even though unsuccessful, had considerable consequences for Portuguese settlers at Nagapattinam. The citizen of Nagapattinam requested the Portuguese Viceroy in Goa to provide the town with walls and towers for its defence. The Portuguese at Nagapattinam also agree to pay the customs duties to the King of Portugal. The Viceroy discussed the issue of fortifying Nagapattinam with the state council in Goa and decided in favour of it on 28 July 1642. When the work started the nayak of Tanjaver sent a force to siege the town of Nagapattinam since permission was not taken for the fortification of the town. Later, the Portuguese requested for the desirable permission, it was granted, and with the approval of the nayak the works resumed. The permission to have major fortifications with a strong fort in a way helped the nayak to take shelter at Nagapattinam when his capital was attacked for the second time (On 8 march 1649) by the army of the Bijapur Sultan. ${ }^{75}$ Thus, the Portuguese settlement of Nagapattinam came under the protection of the King of Portugal.

On 31 December 1642, it was officially incorporate into the Estado da India. The negotiations were complete by late 1643, and Nagapattinam granted the title of Cidade with a Camara municipal replacing the earlier institutions of the Eletios. A Captain-Major was appointed over the place, and the Captain of the settlement was reduced to the captaincy of the garrison sent from Goa to

\footnotetext{
72 Subramanyam, Sanjay, (1990). Improvising Empire, pp. 86-87.

${ }^{73}$ Subramanyam, Sanjay, (1990). Improvising Empire, pp. 86-88.

${ }^{74}$ Stephen, S Jeyaseela, (1998). Portuguese in the Tamil Coast, p. 239.

${ }^{75}$ Stephen, Jeyaseela, (1998). Portuguese in the Tamil Coast, pp. 77-79.
} 
the port. The regulation of the customhouse was finalize by the Crown in January 1645, and accepted by the settlers in October at the same year. Harsh export duties at a rate of 7 per cent were collect in all the goods of the Portuguese, Hindus and Muslims (which included 1 per cent towards the cost of fortification). Besides, there would be an entry duty of 5 per cent on all goods and even gold and silver were to pay two percent.

Still then, the matter did not end here for the Portuguese settler at Nagapattinam as the Dutch were still prowling, and to end the Nagapattinam nuisance once for all and for the prosperity of the VOC a proposal to attack in 1657 was send to the Council at Batavia. This proposal was turn down but in the following year, the decision was consider again. To chalk out their plan a Dutch Squadron arrived at Nagapattinam on 20 July 1658, and the Portuguese surrendered three days later after a casual fight. ${ }^{76}$

The Portuguese surrendered because they preferred to negotiate for the best terms possible under the circumstances, and to remain poor in honour but not destroyed and affronted. Thus, it was on 23 July 1658, facing the prospect of bombardment by a Dutch fleet under Janvander Laan, the Portuguese surrendered their fort and agreed to leave the town on condition of being allowed to carry their moveable possessions and families with them. Some of them remained as brokers and employees of the Dutch Nagapattinam. ${ }^{77}$ After 1658 , the Portuguese community quite clearly appears to have accepted the changed circumstances, and most of them continuing to operate within a framework where the Dutch set the rules.

The coming of the Dutch and English took the advantage of the Portuguese weakness. These new arrival were entering the Portuguese territory, to some extent to displaced the fortified settlement and encroached the profited trading place. The challenged faced by the Portuguese were no doubt people from countries where scientific and technological developments were beginning to lead to a qualitative change, thus the arrival of such people was inevitably going to dispossess the Portuguese. ${ }^{78}$ The multi-pronged attacks by the Dutch in the Portuguese trading ports were the immediate effect in the vast diaspora and it foresees the decline of Portuguese sea borne empire. The Portuguese in Coromandel is no exception as there settlements in San Thome and Nagapatnam both saw the opportunity to develop in the sixteenth century but it was too late to realize their dream to continue in the seventeenth century. By the time, they know the threat the Estatdo de India had powerless to defend in these vast oceanic networks, with no strategy the multi-pronged attacks by the Dutch and the English engulfed their settlement, which they simply watch as a mute spectator. The sixteenth century may be the Portuguese century but the coming seventeenth century was the year for the Dutch and English.

Acknowledgement: I take this opportunity to thank Professor Yogesh Sharma, Centre for Historical Studies, Jawaharlal Nehru University, for bringing this far of my research. He was there from the very beginning of my research from $\mathrm{M}$. A tutorial presentation to $\mathrm{M}$. Phil, $\mathrm{Ph} \mathrm{D}$ and later Post Doctoral Research. He continually shows me the importance of research and taught me valuable lesson in my further studies. Without his guidance and supervision it would be impossible for me to reach this far. In spite of my poor background Professor Yogesh Sharma, continue to encourage regardless of his busy schedule. Whenever I seek any assistance, he never hesitates to instruct me in the right direction. Only I can say is "Thank you" straight from my heart and my prayer is always with you. Apart of this I am very grateful to the University Grant Commission for giving me Post Doctoral Fellowship, which I am very indebted without this financial assistance I would not able to pursue further studies.

\footnotetext{
${ }^{76}$ Foster, William (ed.), (1921). The English Factories in India, 1655-1660, p. 176.

${ }^{77}$ Subrahmanyam, Sanjay, (1990). Improvising Empire, p. 81.

${ }^{78}$ Pearson, M. N. (1987). The Portuguese in India, p.133.
} 


\section{References}

Boxer, C. R. (1965). Portuguese Society in the Tropics. The Municipal Councils of Goa, 1510 -1800, Madison: University of Wisconsin Press.

Campos, J. J, (1919). History of Portuguese in Bengal, Calcutta: Bulterworth and Co.

Costelloe, M. Joseph, (trans.), (1977). Francis Xavier,His life, His time, 1541-1545, by Georg Schurhammer, Rome: Jesuit Historical Institute.

Cummins, J.S., (ed.), (1962). The Travels and Controversies of Friar Domingo Navarette, Cambridge: Haklyut Society.

Greenlee, William B. (ed.), (1938). The Voyage of Pedro Alvares Cabral to Brasil and India, London: Hakluyt Society.

Foster, William (ed.), (1921). The English Factories in India, 1655-1660, Oxford: Clarendon Press. Foster, William (ed.), (1923). The English Factories in India, 1661-1664, Oxford: Clarendon Press.

Irvine, William, (trans.), (1990). Storia Do Mogor or Mogul India, 1652-1708, by Niccolao Manucci, 3 Vols, Delhi: Low Price Publication Reprint.

Love, H.D, (1996). Vestiges of Old Madras, Vol. I, New Delhi: Asian Educational Services Reprint.

Maria Augusta Lima Cruz, "Exile and Renegades in early sixteenth century Portuguese India," The Indian Economic and Social History Review, 23. 3. 1986.

Medlycott, A. E. (1905), India and the Apostle Thomas, In Inquiry With a Critical Analysis of the Act a Thoma, London: David Nutt, Long Acre.

Meersman, Achilles, (1962). The Franciscans in Tamiland, Schoneck: Nouvelle Revue de Science Missionaire.

Mundadan, A. M. "The Portuguese settlement in Mylapore and Traditions about the Indian Apostolate St. Thomas and the tomb of Mylapur." Indian Church History Review, Vol. III, No. I. June 1969.

Mundadan, A. M, (1984). History of Christianity in India, Vol. I, Bangalore: Church History Association of India.

Pearson, M.N, (1987). The Portuguese in India, Bombay: Orient Longman.

Sastri, K. A. Nilakantha, (1958), A history of South India from Prehistoric times to the fall of Vijayanagra, London: Oxford University Press.

Scammel, G.V,"European Exiles, Renegades and Outlaws and Maritime Economy Asia,"1500-1750, Modern Asian Studies, 1992, 24.4.

Stephen, S. Jeyaseela, (1997). Coromandel Coast and its Hinterland, Economy, Society and Political System, (A. D. 1500-1600), New Delhi: Manohar.

Stephen, S. Jeyaseela, (1998). Portuguese in the Tamil Coast,Historical Exploration in Commerce and Culture, 1507-1749. Pondicerry, Navajothi Publishing House. 
Subramanyam, Sanjay (1990). The Political Economy of Commerce, Southern India, 1500-1650, Cambridge: Cambridge University Press.

Subramanyam, Sanjay, (1990), Improvising Empire, Portuguese Trade and Settlement in the Bay of Bengal, 1500-1700, Delhi: Oxford University Press.

Subramanyam, Sanjay, (1993). The Portuguese Empire in Asia, 1500-1700, London: Longman.

Thekkedath, J, (1969). History of Christianity in India, From the Middle of the $16^{\text {th }}$ Century to $17^{\text {th }}$ Century, 1542-1700, Vol. II, Bangolore: Church History Association of India.

Winius, George. D, (2001). Studies on Portuguese Asia, 1495-1689, Hampshire: Variorum Aldershoot.

Varadarajan, Lotika, (ed.), (1981-1985). India in the $17^{\text {th }}$ century, Memoris of Francois Martin, 16701694, Vol. I, Part. III, New Delhi: Manohar. 